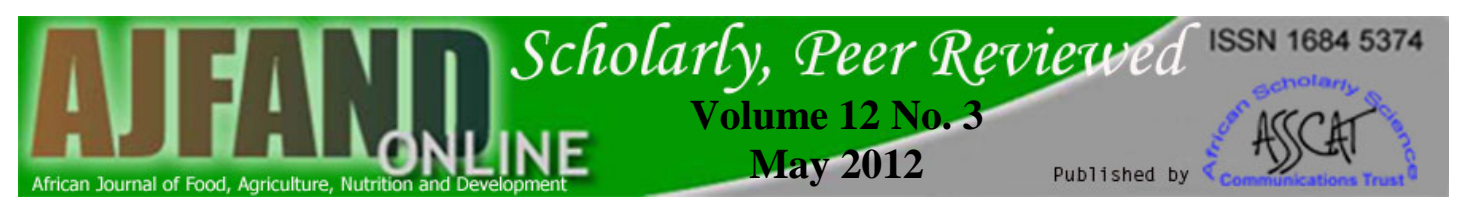

\title{
HETEROSIS OF QUALITATIVE AND QUANTITATIVE CHARACTERS IN SWEET GOURD (Cucurbita moschata Duch.ex Poir)
}

Jahan TA ${ }^{1}$, Islam AKMA ${ }^{1}$, Rasul MG ${ }^{1}$, Mian MAK ${ }^{1}$ and MM Haque ${ }^{2}$

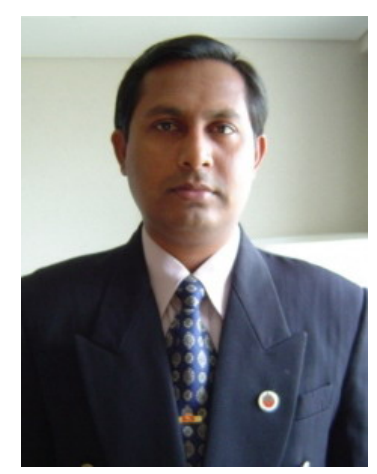

Aminul Islam

* Corresponding author: pulak292003@gmail.com

${ }^{1}$ Department of Genetics and Plant Breeding, Bangabandhu Sheikh Mujibur Rahman Agricultural University, Gazipur 1706, Bangladesh

${ }^{2}$ Department of Agronomy, Bangabandhu Sheikh Mujibur Rahman Agricultural University, Gazipur 1706, Bangladesh 


\section{ABSTRACT}

The heterotic effects and genetic components of variation for qualitative and quantitative characters were estimated in sweet gourd. The phenotypic coefficients of variation were higher than genotypic coefficient of variation for all the characters indicating that environment played a considerable role on the expression of these characters. High heritability coupled with high genetic advance found in parents and hybrids for number of fruits per plant, individual fruit weight and fruit yield suggested that improvement would be effective through phenotypic selection. Both positive and negative heterosis was observed for different qualitative and quantitative characters in $F_{1}$ hybrids of sweet gourd. None of the hybrids exhibited maximum heterosis for all the traits, but significant and desirable level of heterosis over mid parent and better parent was obtained in several hybrids for the different traits. For node number of first female flower, two hybrids, OP $10 \times \mathrm{OP} 24$ and OP $10 \times \mathrm{OP} 20$ recorded the highest significant positive mid and better parent heterosis, respectively. The highest significant $(\mathrm{p}<0.05)$ positive mid and better parent heterosis for female flowers per plant was exhibited by the hybrid OP $20 \times$ OP 02. Significant $(p<0.05)$ and desirable level of mid and better parent heterosis was exhibited by six and four hybrids, respectively, for fruits per plant and fruit yield per plant. The hybrids OP 10×OP 20 and OP $20 \times$ OP 02 showed the highest significant $(\mathrm{p}<0.05)$ positive mid parent and better parent heterosis for \% reducing sugar, respectively. None of the hybrids showed significant ( $p>0.05$ ) heterosis over mid and better parent for brix content. The hybrids OP $10 \times$ OP 02 and OP $04 \times$ OP 02 showed significant mid parent heterosis for carotene content. Four hybrids, OP 10×OP 20, OP 20×OP 02, OP 10×OP 02 and OP 04×OP 02 exhibited significant $(\mathrm{p}<0.05)$ positive heterosis for majority of the characters studied and were identified as promising for commercial cultivation. We concluded that performance of these hybrids needs to be further evaluated in multi location or on farm trial prior to commercial use.

Key words: Pumpkin, nutrition, carotene, brix, hybrids 


\section{INTRODUCTION}

Sweet gourd (Cucurbita moschata Duch. ex Poir.) is a seed propagated, day-neutral, monoecious climbing herb that belongs to the family Cucurbitaceae [1]. Sweet gourd grows throughout the tropical and sub-tropical regions of the world. Pumpkin is also widely grown throughout Africa. It is a common vegetable crop in Bangladesh. It is locally known as 'Misty kumra' or Misty lau' or Misty kadu' and is popular among the rural people. It is grown round the year in Bangladesh and has the longest storability among all the cucurbits. The well-matured fruits (ripe fruits) can be stored for 2 to 4 months [2]. African consumers value the fruit for its long storage capacity and high nutritious value. In Bangladesh, the total area under cultivation of sweet gourd is 4658 ha with a total production of 27830 tonnes (t) [3]. Pumpkin is relatively high in energy and carbohydrates and a good source of vitamins, especially high carotenoid pigments and minerals [4,5]. It may certainly contribute to improve nutritional status of the people, particularly the vulnerable groups in respect of vitamin A requirement. Among the non-traditional crops, sweet gourd has contributed handsomely to the economy of Bangladesh and has been a good source of foreign currency earnings through exports to the U.K, Pakistan, and Middle East [6].

There are number of local cultivars with wide range of variability in size, shape and color of fruits available in Bangladesh $[7,8]$ and for this we can easily fulfill the gap by developing high yielding hybrid variety. The productivity of local genotypes ranged from 6.931t/ha to 19.07t/ha [9]. Though a fairly common crop, to-date there is no released variety of pumpkin with high yield potential and better quality in Bangladesh. Furthermore, very limited attempt has been made for genetic improvement of this crop. Heterosis or hybrid vigor can play a vital role in increasing the yield quality of pumpkin. It refers to the phenomenon in which $F_{1}$ hybrid obtained by crossing of two genetically dissimilar inbred lines or genotypes, shows increased or decreased vigor over the better parent or mid parent value [10]. In cucurbits, heterosis was first noted by Hays and Jones [11]. Due to monoecism, there exists much scope for exploitation of heterosis in sweet gourd and virtually obligatory outcrossing system of sweet gourd open the scope of hybrid variety. Therefore, there is bright scope to study the heterosis, which is the prerequisite for developing high yielding sweet gourd variety or hybrid variety. Considering the above idea in mind the present investigation was undertaken with the objectives (i) to determine the magnitude of heterosis as well as hybrid performance for some desirable yield contributing characters and (ii) to identify high heterotic parental combination in order to develop hybrid variety.

\section{MATERIALS AND METHODS}

This investigation was carried out at the Research Farm of the Bangabandhu Sheikh Mujibur Rahman Agricultural University (BSMRAU), Salna, and Gazipur, Bangladesh during December 2007 to April 2008. Ten hybrids of pumpkin prepared in previous year and their eight parents (OP 02, OP 04, OP 10, OP 16, OP-20, OP 23, OP 24, OP $10 \times$ OP 02 , OP $10 \times$ OP 20 , OP $4 \times$ OP 16 , OP $20 \times$ OP 02 , OP $04 \times$ OP 02 , OP $04 \times$ OP 20, OP $16 \times$ OP 20 , OP $23 \times$ OP 24 , OP $10 \times$ OP 24 and OP $02 \times$ OP 20) were 
used as experimental materials. Two seeds were sown in each poly bag with $9 \mathrm{~cm}$ diameter. The germination medium was prepared by mixing compost and soil in proportion of 1:1. Intensive care was taken for production of healthy seedlings. The plots were raised $10 \mathrm{~cm}$ above the ground level and pits of $50 \times 50 \times 50 \mathrm{~cm}$ size were dug at a spacing of $2 \times 2 \mathrm{~m}$. Recommended doses of manure and fertilizers were applied in the experimental field according to BARI [12]. Twenty four day-old seedlings were transplanted in well prepared experimental plots. The seedlings were watered immediately after transplanting. Four plants of each genotype were accommodated in each replicated plot maintaining $2 \times 2 \mathrm{~m}$ spacing. The experiment was laid out in a randomized complete block design (RCBD) with three replications. Intercultural operations including weeding, irrigation, and pesticide applications were done when necessary during the growing period for proper growth and development of the plants and to protect the fruits from rotting. The fruits were harvested when the peduncle dried on maturity.

Three plants were selected at random from each plot for recording data. Data were recorded on both qualitative characters (\% reducing and non-reducing sugar, \% brix and \% carotene content) and quantitative (nodes for first female flowers, number of female flowers per plant, number of nodes for first fruit setting, fruit weight in $\mathrm{kg}$, number of fruits per plant, yield per plant in kg). Brix (\%) content was measured with the help of a Brix meter (Model: ATAGONI Brix 0-32\%, Made in Japan). Sugar contents (reducing and non-reducing) were estimated by the method of Somogyi [13]. Carotene content was measured by the following formula:

$\beta$-carotene $(\mathrm{mg})=0.216$ [Reading at $663 \mathrm{~nm}]+0.452$ [Reading $453 \mathrm{~nm}$ ] -1.22 [Reading at $645 \mathrm{~nm}$ ] -0.304 [Reading at $505 \mathrm{~nm}$ ]

The data of the present study were statistically analyzed by using SAS statistical package [14]. The mean square of error and phenotypic variance were estimated according to Johnson et al. [15]. Genotypic and phenotypic coefficients of variation (GCV and PCV) were calculated by the formula suggested by Burton [16] and AlJibouri et al. [17]. The broad sense heritability and genetic advance in percentage of mean were calculated following Lush [18] and Hanson [19]. Heterosis was recorded as mid parent heterosis $(\mathrm{Hm})$ and better parent heterosis $(\mathrm{Hb})$ from mean values according to the formula adopted by Falconar and Mackay [20], and was estimated following Mather and Jink [21]. Student's t-test was used to test the significant $(p<0.05)$ differences of $F_{1}$ mean over better parent and mid parent [22].

\section{RESULTS}

\section{Genetic variability}

The result presented here provides some information on genetic variability and heterosis for qualitative (nutrition related) and quantitative (yield related) characters. The analysis of variance (Table 1$)$ indicated the existence of significant $(p<0.05)$ variability for most of the characters studied except fruits per plant, individual fruit weight, \% reducing sugar, \% non-reducing sugar and \% carotene content among the genotypes. The mean, range, genotypic and phenotypic variance, genotypic and 
phenotypic coefficient of variation, heritability estimates, genetic advance and genetic advance in percent of mean are presented in Table 1 and Table 2 for parents and hybrid, respectively. The phenotypic coefficients of variation were higher than the genotypic coefficient of variation for all the character studied. Out of ten characters, fruits per plant and number of female flower showed the highest difference between genotypic and phenotypic coefficients of variation (GCV and PCV) and remaining characters showed little difference. The characters, number of nodes for first female flower, number of nodes for first fruit setting, individual fruit weight and fruit yield per plant showed high genetic advance in \% of mean in association with high heritability.

\section{Heterosis}

The heterotic responses of $F_{1}$ hybrids over mid parent (MP) and better parent (BP) for ten characters are presented in Table 3 and Table 4, respectively. The lowest number of nodes for first female flower, higher number of female flowers per plant, higher number of fruits per plant, higher fruit weight and higher yield were treated as the parameters of better parent. Both positive and negative heterosis was observed for different qualitative and quantitative characters in $\mathrm{F}_{1}$ hybrids of sweet gourd. It was noticed that the heterotic performance of the hybrids over their mid parental values were mostly positive. Mid parent heterosis and heterobeltiosis varied from -17.90 to $27.81 \%$ and -25.13 to $23.20 \%$ for female flower, respectively (Table 3 and 4 ). Five hybrids, OP $10 \times$ OP $02\left(16.36^{* *} \& 10.87^{* *}\right)$, OP 10×OP 20 (23.71** \& 23.20**), OP $20 \times$ OP $02\left(19.08^{* *} \& 13.04 * *\right)$, OP $10 \times$ OP $24\left(27.81^{* *} \& 16.45^{* *}\right)$ and OP $02 \times$ OP $20\left(22.93^{* *} \& 16.67^{* *}\right)$ showed significant $(\mathrm{p}<0.05)$ positive mid and better parent heterosis, respectively for node number of first female flower. Remaining characters showed negative heterosis but none of them were significant $(p>0.05)$. There was a significant variation for both mid parent heterosis and heterobeltiosis for number of female flowers per plant. Mid parent heterosis ranged from -23.32 to 30.08 (Table 3) and heterobeltiosis varied from -32.95 to 20.78\% (Table 4) for female flowering. The highest significant $(\mathrm{p}<0.05)$ positive mid and better parent heterosis for female flowers per plant was exhibited by the hybrid OP 20×OP 02 (30.08** and $20.78^{* *}$, respectively) followed by OP $04 \times$ OP 20 (16.33** and 9.09**, respectively). The hybrids OP $20 \times$ OP 02 , OP $10 \times$ OP 02 , OP $04 \times$ OP 16 , OP $23 \times$ OP 24 , OP $10 \times$ OP 24 and OP $02 \times$ OP 20 showed significant $(\mathrm{p}<0.05)$ heterosis for number of nodes for first fruit setting in positive direction but none of the hybrid showed significant ( $>0.05$ ) negative heterosis for this character. Five hybrids, OP $20 \times \mathrm{OP} 02$, OP $10 \times \mathrm{OP}$ 20 , OP $10 \times$ OP 02 , OP $04 \times$ OP 20 and OP $10 \times$ OP 24 showed significant $(\mathrm{p}<0.05)$ positive mid and better parent heterosis for fruits per plant. The highest significant $(\mathrm{p}<0.05)$ positive mid and better parent heterosis for individual fruit weight was observed in the hybrid OP $10 \times$ OP $20\left(17.45^{* *} \& 16.45^{* *}\right)$. Only four hybrids, OP $10 \times$ OP 02 , OP $10 \times$ OP 20, OP $20 \times$ OP 02 and OP $10 \times$ OP 24 showed significant $(\mathrm{p}<0.05)$ positive heterosis (both mid and better parents) for fruit yield per plant. The highest significant $(\mathrm{p}<0.05)$ positive mid parent $\left(48.49^{* *}\right)$ and better parent $\left(30.55^{* *}\right)$ heterosis for fruit yield per plant was found in the hybrids OP $10 \times \mathrm{OP} 24$ and OP $10 \times$ OP 20, respectively. The highest significant $(\mathrm{p}<0.05)$ positive mid parent $\left(9.54^{* *}\right)$ and better parent $\left(45.65^{* *}\right)$ heterosis for \% reducing sugar was found in the hybrids OP $10 \times$ OP 20 and OP $20 \times$ OP 02, respectively. On the other hand all the hybrids

Published by African Scholarly Science Communications Trust
Josem Trust Place, Bunyala Road, Upper Hill, Nairobi
$\begin{aligned} & \text { P.O. Box 29086-00625 Tel: +254-20-2351785 Fax: }+254-20-4444030, \text { Nairobi, KENYA } \\ & \text { Email: oniango@iconnect.co.ke OR info@ajfand.net } \quad \text { www.ajfand.net }\end{aligned}$


showed non-significant $(\mathrm{p}>0.05)$ negative heterosis over better and mid parent for non-reducing sugar \%. None of the hybrids showed significant $(\mathrm{p}>0.05)$ heterosis over mid and better parent for brix content. The hybrids OP $10 \times \mathrm{OP} 02$ and OP $04 \times \mathrm{OP}$ 02 showed significant $(\mathrm{p}<0.05)$ mid parent heterosis for carotene content.

\section{DISCUSSION}

Analysis of variance showed significant $(\mathrm{p}<0.05)$ differences among the genotypes for all the characters except node number of first male flower, fruits per plant and individual fruit weight. The phenotypic coefficients of variation were higher than genotypic coefficient of variation for all the character studied indicating predominance of environmental effects on the expression of these characters. Fruits per plant and number of female flowers per plant showed the highest difference between GCV and PCV, indicating relatively higher influence of environmental effect on the expression of these characters. Genotypic and phenotypic coefficient of variations and high heritability along with moderate genetic advance (GA) in percent of mean were estimated for number of nodes for first female flower. Significant differences for nodes of first male and female flower were observed in pumpkin [23] and in summer squash [24]. High heritability with high GA \% was found in parents and hybrids which suggested that improvement of number of fruits per plant would be effective through phenotypic selection. Wide range of variability for number of fruits per plant and fruit yield per plant was observed in pumpkin [25]. Hamid et al. [9] found a wide range of variability among the lines in respect of their flowering habit, fruit bearing, weight and size of fruit in ash gourd. High heritability coupled with high GA suggested that effective selection might be done for fruit yield per plant in both the parental and hybrid generation. The results of genetic variability study suggested that environment plays a considerable role in expressing fruit yield per plant. High heritability was reported for yield per stem and eight related characters and relatively high genetic advance for fruit diameter and fruit length [26].

The aim of heterosis study was to identifying the best heterotic combinations and its exploitation for commercial purpose. None of the hybrids in this study had recorded maximum heterosis for all the traits, but significant and desirable level of heterosis over mid parent and better parent was obtained in several hybrids for the different traits. For node number of first female flower, five hybrids showed significant positive heterosis. The hybrids OP $10 \times \mathrm{OP} 24$ and OP $10 \times \mathrm{OP} 20$ showed the highest significant positive mid and better parent heterosis, respectively. Significant $(p<0.05)$ positive heterosis was observed for number of nodes for first female flowering, fruits per plant, fruit weight, yield per plant among several genotypes in sweet gourd [27]. Saha et al. [28] reported 15.5 to 27.0 nodes for first female flower bearing among the pumpkin genotypes. The highest significant $(\mathrm{p}<0.05)$ positive mid and better parent heterosis for female flowers per plant was exhibited by the hybrid OP $20 \times \mathrm{OP} 02$ followed by OP $04 \times$ OP 20. Solanki et al. [29] recorded maximum heterosis (42.12\%) for number fruits per plant in cucumber hybrid. The highest significant $(p<0.05)$ positive mid and better parent heterosis for individual fruit weight was observed in the hybrid OP $10 \times$ OP 20. Significant $(\mathrm{p}<0.05)$ and desirable level of mid parent heterosis was observed in six hybrids for fruit yield per plant and better parent heterosis in four

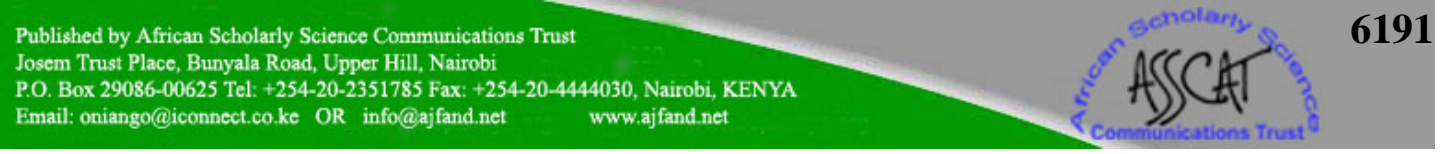




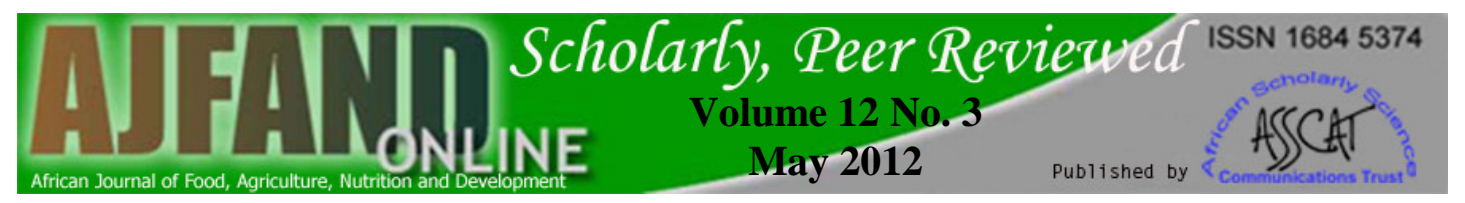

hybrids. Only one hybrid (OP 10×OP 20) for mid parent heterosis and another one (OP 20×OP 02) for better parent heterosis showed significant $(\mathrm{p}<0.05)$ positive value for all the yield related traits including fruit yield per plant. Six hybrids in both case showed significant and desirable heterosis for number of fruits per plant. The mid and better parent heterosis was observed to be as high as $~ 165 \%$ for yield per vine in ash gourd [30]. High heterosis over the better parent was observed for number of female flower, number of fruits per plant, fruit weight and yield per plant in pumpkin [27]. Varietal effects and heterosis for number of female flower, fruits per plant and fruit weight were also observed in pumpkin by Gwanama et al. [31]. The hybrids OP $10 \times$ OP 20 and OP $20 \times$ OP 02 showed the highest significant $(\mathrm{p}<0.05)$ positive mid parent and better parent heterosis for \% reducing sugar, respectively. The hybrids OP $10 \times$ OP 02 and OP $04 \times$ OP 02 showed significant $(\mathrm{p}<0.05)$ mid parent heterosis for carotene content.

\section{CONCLUSION}

The hybrids OP $10 \times \mathrm{OP} 20$ and OP $20 \times \mathrm{OP} 02$ showed positive heterosis in all the yield related traits studied. Only four hybrids exhibited significant $(\mathrm{p}<0.05)$ and desirable levels of heterosis over both mid and better parent. The cross combinations OP $10 \times$ OP 20 , OP $20 \times$ OP 02 , OP $10 \times$ OP 02 , OP $04 \times$ OP 02 showed significant $(\mathrm{p}<0.05)$ positive mid parent heterosis and heterobeltiosis revealed the over dominance type of gene action operating these crosses. These cross combinations could be identified as desirable hybrids for commercial cultivation. So these four hybrids (OP $10 \times \mathrm{OP} 20$, OP $20 \times \mathrm{OP} 02$, OP $10 \times \mathrm{OP} 02$ and $\mathrm{OP} 04 \times \mathrm{OP} 02$ ) were identified as promising for commercial cultivation. Performance of these hybrids needs to be evaluated in multi location and on farm trial prior to commercial use. 


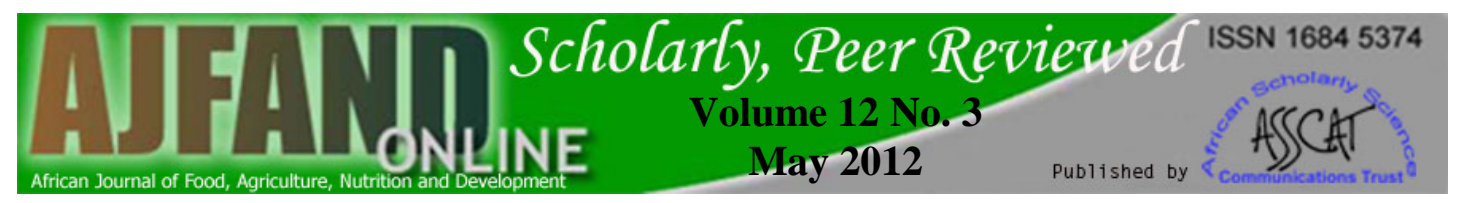

Table 1: Performance of eight parents involved in hybrid combination for six quantitative characters in sweet gourd

\begin{tabular}{|l|c|c|c|c|c|c|}
\hline Parents & $\begin{array}{c}\text { Nodes of } \\
\text { first female } \\
\text { flower (no) }\end{array}$ & $\begin{array}{c}\text { Female } \\
\text { flowers } \\
\text { per plant } \\
\text { (no) }\end{array}$ & $\begin{array}{c}\text { Nodes of } \\
\text { first fruit } \\
\text { setting } \\
\text { (no) }\end{array}$ & $\begin{array}{c}\text { Fruits } \\
\text { per plant } \\
\text { (no) }\end{array}$ & $\begin{array}{c}\text { Individual } \\
\text { fruit weight } \\
\text { (kg) }\end{array}$ & $\begin{array}{c}\text { Fruit yield } \\
\text { per plant } \\
\text { (kg) }\end{array}$ \\
\hline OP 10 & 17.88 & 9.23 & 20.38 & 3.23 & 3.03 & 9.53 \\
\hline OP 02 & 23.38 & 8.23 & 24.98 & 2.86 & 3.51 & 6.71 \\
\hline OP 26 & 19.13 & 9.23 & 21.48 & 3.61 & 4.84 & 13.73 \\
\hline OP 04 & 17.48 & 11.01 & 20.03 & 4.48 & 4.01 & 18.28 \\
\hline OP 16 & 22.13 & 10.36 & 23.88 & 4.48 & 3.59 & 15.68 \\
\hline OP 23 & 17.23 & 12.63 & 19.78 & 4.86 & 2.96 & 14.18 \\
\hline OP 24 & 17.23 & 10.51 & 20.38 & 3.61 & 3.97 & 13.98 \\
\hline OP 20 & 19.13 & 9.61 & 21.78 & 2.86 & 3.07 & 11.06 \\
\hline F-value & $* *$ & $* *$ & $* *$ & NS & NS & $* *$ \\
\hline Mean & 19.20 & 10.10 & 21.59 & 3.75 & 3.62 & 12.89 \\
\hline$\sigma^{2}$ p & 7.23 & 2.77 & 5.35 & 0.78 & 0.52 & 18.60 \\
\hline$\sigma^{2}$ g & 4.60 & 1.31 & 2.82 & 0.40 & 0.35 & 10.70 \\
\hline GCV & 11.17 & 11.31 & 7.78 & 16.69 & 16.34 & 25.33 \\
\hline PCV & 14.00 & 16.47 & 10.71 & 23.16 & 19.76 & 33.40 \\
\hline Heritability & 63.68 & 47.21 & 52.75 & 51.95 & 68.35 & 57.51 \\
\hline GA & 4.52 & 2.08 & 3.22 & 1.21 & 1.30 & 6.55 \\
\hline GA \% mean & 23.53 & 20.52 & 14.92 & 31.77 & 35.66 & 50.71 \\
\hline
\end{tabular}

NS $=$ Not significant, $*$ and $* *$ indicates significant at 5 and $1 \%$ level

$\sigma^{2} \mathrm{~g}=$ Genotypic variance, $\sigma_{\mathrm{p}}^{2}=$ Phenotypic variance, PCV = Phenotypic coefficient of variance, GCV = Genotypic coefficient of variance, $\mathrm{GA}=$ Genetic advance 


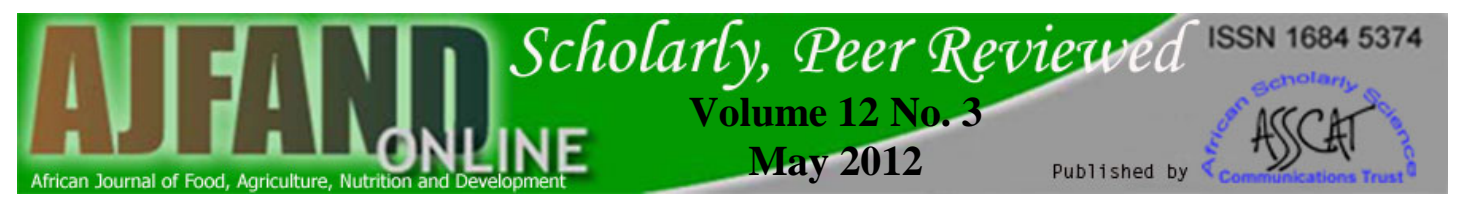

Table 2: Performance of ten hybrids for six quantitative characters in sweet gourd

\begin{tabular}{|l|c|c|c|c|c|c|}
\hline Hybrids & $\begin{array}{c}\text { Nodes of } \\
\text { first female } \\
\text { flower (no) }\end{array}$ & $\begin{array}{c}\text { Female } \\
\text { flowers } \\
\text { per plant } \\
\text { (no) }\end{array}$ & $\begin{array}{c}\text { Nodes of } \\
\text { first fruit } \\
\text { setting } \\
\text { (no) }\end{array}$ & $\begin{array}{c}\text { Fruits } \\
\text { per plant } \\
\text { (no) }\end{array}$ & $\begin{array}{c}\text { Individual } \\
\text { fruit weight } \\
(\mathrm{kg})\end{array}$ & $\begin{array}{c}\text { Fruit yield } \\
\text { per plant } \\
(\mathrm{kg})\end{array}$ \\
\hline OP 10 $\times$ OP 02 & 17.23 & 8.98 & 21.36 & 3.86 & 3.27 & 12.49 \\
\hline OP 10 $\times$ OP 20 & 19.23 & 9.98 & 20.23 & 4.11 & 3.58 & 14.46 \\
\hline OP 04 $\times$ OP 16 & 19.23 & 10.73 & 21.11 & 4.23 & 2.82 & 12.08 \\
\hline OP 20 $\times$ OP 02 & 20.11 & 11.61 & 23.36 & 4.23 & 3.77 & 16.13 \\
\hline OP 04 $\times$ OP 02 & 18.98 & 7.36 & 21.61 & 2.61 & 2.76 & 7.21 \\
\hline OP 04 $\times$ OP 20 & 19.48 & 11.98 & 20.73 & 4.73 & 3.74 & 16.96 \\
\hline OP 16 $\times$ OP 20 & 15.61 & 10.11 & 18.73 & 3.98 & 3.28 & 12.91 \\
\hline OP 23 $\times$ OP 24 & 15.48 & 10.48 & 19.98 & 3.73 & 3.64 & 14.11 \\
\hline OP 10 $\times$ OP 24 & 17.61 & 9.98 & 19.61 & 4.36 & 4.05 & 17.45 \\
\hline OP 02 $\times$ OP 20 & 17.98 & 8.98 & 20.36 & 2.98 & 3.26 & 9.62 \\
\hline F-value & $* *$ & $* *$ & $* *$ & NS & NS & $* *$ \\
\hline Mean & 18.09 & 10.01 & 20.70 & 3.88 & 3.42 & 13.34 \\
\hline$\sigma^{2} p$ & 3.18 & 3.55 & 2.05 & 0.69 & 0.23 & 13.67 \\
\hline$\sigma^{2}$ g & 2.30 & 0.95 & 1.38 & 0.27 & 0.14 & 8.76 \\
\hline GCV & 8.38 & 9.69 & 5.66 & 13.35 & 10.96 & 22.15 \\
\hline PCV & 9.84 & 18.78 & 6.91 & 21.36 & 14.08 & 27.67 \\
\hline Heritability & 72.55 & 26.63 & 67.03 & 39.08 & 60.58 & 64.09 \\
\hline GA & 3.41 & 1.33 & 2.54 & 0.86 & 0.77 & 6.26 \\
\hline GA \% mean & 18.85 & 13.20 & 12.23 & 22.04 & 22.52 & 46.81 \\
\hline S $~$ & 13.20 & & \\
\hline
\end{tabular}

NS $=$ Not significant, * and $* *$ indicates significant at 5 and $1 \%$ level

$\sigma^{2} \mathrm{~g}=$ Genotypic variance, $\sigma_{\mathrm{p}}^{2}=$ Phenotypic variance, PCV = Phenotypic coefficient of variance, $\mathrm{GCV}=$ Genotypic coefficient of variance, $\mathrm{GA}=$ Genetic advance 


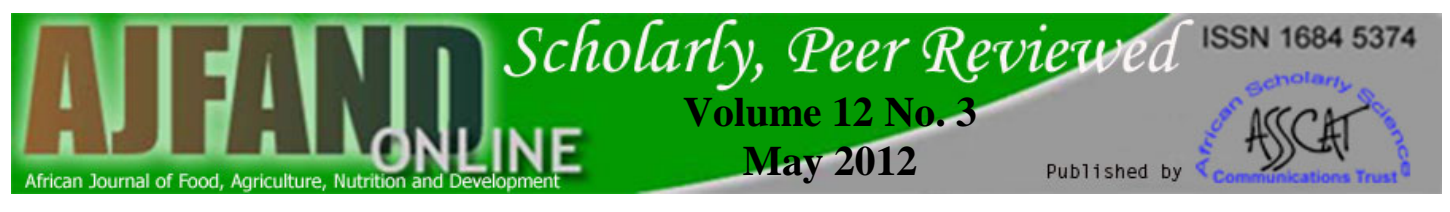

Table 3: Heterosis over mid parent for ten different characters of ten hybrids of sweet gourd

\begin{tabular}{|c|c|c|c|c|c|c|c|c|c|c|}
\hline Characters & $\begin{array}{r}\text { OP } 10 \times \\
\text { OP } 02\end{array}$ & $\begin{array}{r}\text { OP } 10 \times \\
\text { OP } 20\end{array}$ & $\begin{array}{r}\text { OP } 04 \times \\
\text { OP } 16\end{array}$ & $\begin{array}{r}\text { OP } 20 \times \\
\text { OP } 02\end{array}$ & $\begin{array}{r}\text { OP } 04 \times \\
\text { OP } 02\end{array}$ & $\begin{array}{r}\text { OP } 4 \times \\
\text { OP } 20\end{array}$ & $\begin{array}{r}\text { OP } 10 \times \\
\text { OP } 20\end{array}$ & $\begin{array}{r}\text { OP } 23 \times \\
\text { OP } 24\end{array}$ & $\begin{array}{r}\text { OP } 10 \times \\
\text { OP } 24\end{array}$ & $\begin{array}{r}\text { OP } 02 \times \\
\text { OP } 20\end{array}$ \\
\hline $\begin{array}{l}\text { No. nodes of first } \\
\text { female flower }\end{array}$ & $16.36 * *$ & $23.71 * *$ & -17.89 & $19.08 * *$ & -5.47 & -0.72 & -8.02 & -7.52 & $27.81^{* *}$ & $22.93 * *$ \\
\hline $\begin{array}{r}\text { Female flowers per } \\
\text { plant (no) }\end{array}$ & 2.85 & $5.93 * *$ & 0.56 & $30.08 * *$ & -23.32 & $16.33^{* *}$ & 1.25 & -9.21 & 1.26 & -4.66 \\
\hline $\begin{array}{r}\text { Nodes of first fruit } \\
\text { setting (no) }\end{array}$ & $6.20 * *$ & $6.06 * *$ & -2.75 & $6.87 * *$ & $5.49 * *$ & -1.23 & -2.18 & $11.31 * *$ & $27.77 * *$ & $19.37 * *$ \\
\hline Fruits per plant (no) & $26.59 * *$ & $24.58 * *$ & -5.56 & $35.78 * *$ & -28.73 & $20.55 * *$ & 1.53 & -11.87 & 27.33 & -4.15 \\
\hline $\begin{array}{r}\text { Individual fruit weight } \\
\text { (kg) }\end{array}$ & 0.15 & $17.45^{* *}$ & -25.65 & $14.50 * *$ & -26.36 & 5.77 & -1.64 & 5.02 & 15.79 & 4.79 \\
\hline $\begin{array}{r}\text { Fruit yield per plant } \\
(\mathrm{kg})\end{array}$ & $24.66 * *$ & $44.29 * *$ & -28.78 & $49.46 * *$ & -49.88 & $15.43^{* *}$ & $27.00 * *$ & 0.21 & $48.49 * *$ & -10.78 \\
\hline \% Reducing sugar & -23.18 & $9.53 * *$ & -28.66 & -25.79 & -26.41 & -20.48 & -1.00 & -0.99 & -26.59 & -33.40 \\
\hline \% Non reducing sugar & -13.77 & -27.21 & -21.72 & -5.79 & -28.75 & -29.10 & -11.33 & -1.46 & -47.92 & -7.29 \\
\hline \% Brix & -20.66 & -47.62 & -13.15 & -20.00 & -5.00 & -34.12 & -52.97 & -29.03 & -58.33 & -38.95 \\
\hline \% Carotene & $7.69 * *$ & -42.75 & -45.89 & -36.85 & $11.09 * *$ & -40.98 & -61.12 & -8.43 & -48.51 & -41.39 \\
\hline
\end{tabular}

** indicates significant at $1 \%$ level 


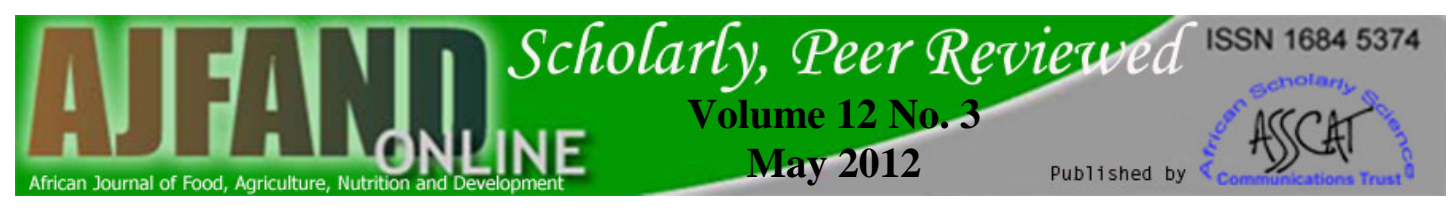

Table 4: Heterobeltiosis for ten different characters of ten hybrids of sweet gourd

\begin{tabular}{|c|c|c|c|c|c|c|c|c|c|c|}
\hline Characters & $\begin{array}{r}\text { OP } 10 \times \\
\text { OP } 02\end{array}$ & $\begin{array}{r}\text { OP } 10 \times \\
\text { OP } 20\end{array}$ & $\begin{array}{r}\text { OP } 04 \times \\
\text { OP } 16\end{array}$ & $\begin{array}{r}\text { OP } 20 \times \\
\text { OP } 02\end{array}$ & $\begin{array}{r}\text { OP } 04 \times \\
\text { OP } 02\end{array}$ & $\begin{array}{r}\text { OP } 4 \times \\
\text { OP } 20\end{array}$ & $\begin{array}{r}\text { OP } 10 \times \\
\text { OP } 20\end{array}$ & $\begin{array}{r}\text { OP } 23 \times \\
\text { OP } 24\end{array}$ & $\begin{array}{r}\text { OP } 10 \times \\
\text { OP } 24\end{array}$ & $\begin{array}{r}\text { OP } 02 \times \\
\text { OP } 20\end{array}$ \\
\hline $\begin{array}{r}\text { No. nodes of first } \\
\text { female flower }\end{array}$ & $10.87 * * *$ & $23.20 * *$ & -25.13 & $13.04^{* *}$ & -10.39 & -10.39 & -23.53 & -7.84 & $16.45^{* *}$ & $16.67^{* *}$ \\
\hline $\begin{array}{r}\text { Female flowers per } \\
\text { plant (no) }\end{array}$ & -2.70 & 3.90 & -2.27 & $20.78 * *$ & -32.95 & $9.09 * *$ & -2.41 & 0.00 & -5.00 & -6.49 \\
\hline $\begin{array}{r}\text { Nodes of first fruit } \\
\text { setting (no) } \\
\end{array}$ & $3.82 * *$ & 1.84 & -5.33 & $4.91 * *$ & 1.77 & -4.14 & -3.07 & $8.09 * *$ & $22.69 * *$ & $17.17 * *$ \\
\hline Fruits per plant (no) & $19.23 * *$ & $22.22 * *$ & -5.56 & $25.93^{* *}$ & -41.67 & $4.75^{* *}$ & -17.95 & -23.08 & $20.69 * *$ & -11.11 \\
\hline $\begin{array}{r}\text { Individual fruit weight } \\
\text { (kg) }\end{array}$ & -6.71 & $16.45^{* *}$ & -29.46 & $7.48 * *$ & -30.79 & -6.45 & -8.91 & -8.23 & 2.03 & -7.02 \\
\hline $\begin{array}{r}\text { Fruit yield per plant } \\
(\mathrm{kg})\end{array}$ & $18.93 * *$ & $30.55 * *$ & -33.97 & $45.65 * *$ & -60.55 & -7.32 & -17.42 & -9.71 & $25.00 * *$ & -13.08 \\
\hline \% Reducing sugar & -31.40 & 0.22 & -31.30 & -38.95 & -33.51 & -28.26 & -7.29 & -22.84 & -31.66 & -45.08 \\
\hline \% Non reducing sugar & -17.99 & -33.37 & -23.61 & -9.54 & -29.30 & -32.43 & -13.45 & -11.85 & -51.89 & -10.98 \\
\hline$\%$ Brix & -25.19 & -48.03 & -19.51 & -24.00 & -15.56 & -44.00 & -57.2 & -42.61 & -58.66 & -42.00 \\
\hline \% Carotene & 0.63 & -53.65 & -50.25 & -45.93 & -3.42 & -42.02 & -64.87 & -7.76 & -54.42 & -49.81 \\
\hline
\end{tabular}

** indicates significant at $1 \%$ level 


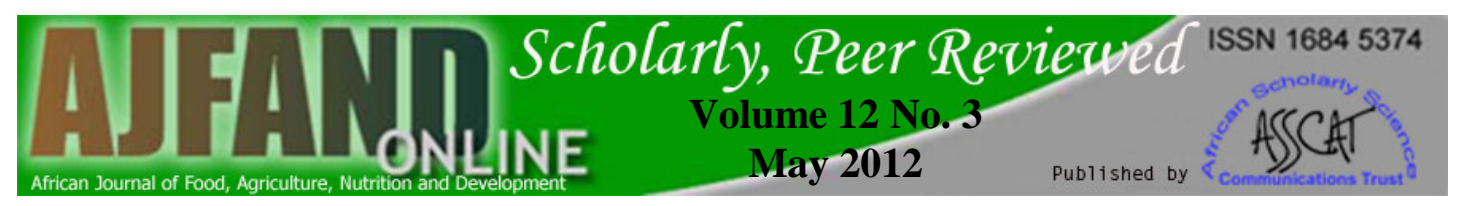

\section{REFERENCES}

1 Katyal SL and ML Chadha Vegetables Growing in India. Oxford and IBH Publishing Co., New Delhi, India, 2000: 92-93.

2 Yawalkar KS Vegetable crop in India. Agri-Horticultural Publishing House, Nagpur, 1991: 182-186.

3 Rashid MM Nutrient component of Pumpkin. Shobji Biggan. Second Edition. Bangla Academy, Dhaka, Bangladesh, 2002: 66-69.

4 Bose TK and MG Som Vegetable Crops in India, Naya Prokash, Calcutta, India, 1998: 92-95.

5 Tindall HD Vegetables in the tropics. Macmillan Education, London, 2001: 166.

6 Alamgir $\mathbf{M}$ Export potential of non-traditional agricultural products (Bangladesh). Bangladesh Quarterly, 1998; 1(3): 12-13.

7 Rashid SS Sabji Biggan (In: Bangla). Bangla Academy, Dhaka, Bangladesh, 1993: 515.

8 Kamaluddin ASM Sabjir Chash (In: Bangla) Kamunnahar, Mahammadpur, Dhaka, Bangladesh, 1996: 258.

9 Hamid MN, Saha MC and RA Begum Physio-morphology and yield of different ash gourd lines. Bangladesh Journal of Agricultural Science 1991; 4(1):51-55.

10 Poehlman JM Breeding Field Crops. $2^{\text {nd }}$ edition Westport, Connection: The AVI Publishing Company, Inc, 1979.

11 Hays HK and DF Jones First generation crosses in cucumber. Conn Agric Expt Sta Ann Rpt 1961: 319-322.

12 BARI Basat Bari Sabji Utpadan (In: Bangla). Bangladesh Agricultural Research Institute, Gazipur, Bangladesh, 1991: 239.

13 Somogyi JM Notes on sugar determination. Journal of Biological Chemistry 1952; 195: 19-23.

14 SAS. SAS/STAT User Installation Guide for SAS ${ }^{\circledR}$ 9.1.3, Foundation for Microsoft ${ }^{\circledR}$ Windows ${ }^{\circledR}$. SAS Institute Inc. Copyright ${ }^{\circledR}$ 2003, Cary, North Carolina, USA. 2008.

15 Johnson HW, Robinson HF and RE Comstock Estimates of genetic and environmental variability in soybeans. Agron Journal 1955; 47(4): 314-318. 
16 Burton GW and EH De Vane Estimating heritability in tall fescue (Festuca arundinacea) from replicated clonal material. Agron Journal 1953; 45:478481.

17 Al-Jibouri HA, Kitter PA and HF Robinson Genotypic and environmental variations and co-variances in an upland cotton cross of interspecific origin. Agron Journal 1958; 50: 533-536.

18 Lush JN Animal Breeding Plans. The Collegiate Press. Amer Iowa. $3^{\text {rd }}$ Edn, 1949.

19 Hanson WD Heritability in Statistical Genetics and Plant Breeding. NAS NRC Publication, Washington, USA, 1961: 125-140.

20 Felconar DS and TFC Mackay Introduction to Quantitative Genetics. Longman, Essex, UK, 1996.

21 Mather $\mathbf{K}$ and JL Jinks Biometrical Genetics ( $2^{\text {nd }}$ Edition). Chapman and Hall, Ltd. London, 1971: 344.

22 Singh RK and BD Chaudhary Biometrical Methods in Quantitative Genetic Analysis. Kalyani Publishers. New Delhi, India, 2006: 318.

23 Mohanty BK and RS Mishra Studies on heterosis for flowering attributes in pumpkin (Cucurbita moschata Duch. ex. Poir). South Indian Horticulture 2002; 47(1-6): 203-205.

24 Raju AMK, Rana MK and MS Dahiya Genetic variability studies in summer squash (Cucurbita pepo L.). Vegetable Science 2002; 25(1): 68-71.

25 Rahman MM, Dey SK and M Wazuddin Yield, yield components and plant characters of several bitter gourds, ribbed gourd, bottle gourd and sweat gourd genotypes. BAU Res Progress 1990; 4: 117-127.

26 Sanhi GP, Singh RK and BS Saha Genetic and phenotypic variability in ridge gourd. Indian Journal of Agricultural Science 1990; 57(9): 666-668.

27 Mohanty BK and RS Mishra Studies on heterosis for yield and yield attributes in pumpkin (Cucurbita moschata Duch. ex. Poir.). Indian Journal of Horticulture 2004; 56(2): 173-178.

28 Saha RR, Mitra BN, Hossain AE, Jamaluddin M and AMM Mosiul Hoque Genetic variability, character association and path co-efficient analysis in pumpkin (Cucurbita moschata L). Bangladesh Horticulture 1992; 20 (1):59-62.

29 Solanki SS, Seth JN and SD Lal Heterosis and inbreeding depression in cucumber. Progressive Hort 1982; 14: 121-125. 


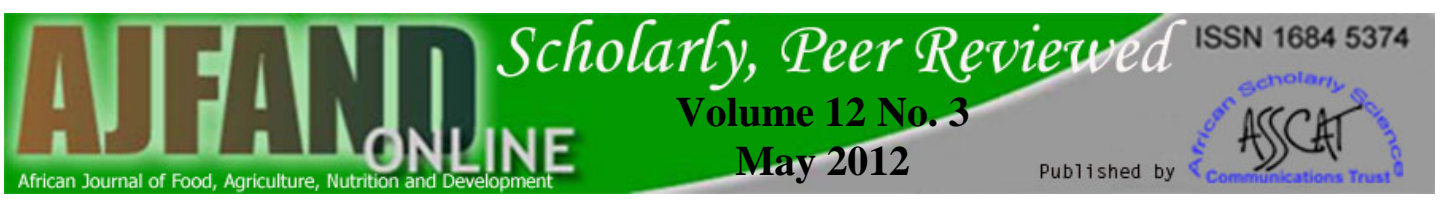

30 Verma VK and TK Behera Heterosis studies in ash gourd[Benincasa hispida (Thunb) Cogn.] for yield and related traits. Journal of Tropical Agriculture 2007; 45(1/2): 51-54.

31 Gwanama C, Botha AM and MT Labuschagne Genetic effects and heterosis of flowering and fruit characteristics of tropical pumpkin. Plant Breeding 2001; 120(3): 271-272. 